J. Environ. Sci.

Institute of Environmental Studies and Research - Ain Shams University

\title{
APHIDS ON MEDICINAL AND AROMATIC PLANTS IN EGYPT (HEMIPTERA: APHIDIDAE)
}

Essam R. Mahmoud ${ }^{(1)}$; Ashraf Helmi ${ }^{(2)}$; Sayed A. Dahroug ${ }^{(2)}$; Mohamed Hewidy ${ }^{(2)}$; and Mona A. Mohamed ${ }^{(1)}$

1) Vegetable Pests Dep., Plant Protection Research Institute, Agricultural Research Center, Dokki, Giza, Egypt. 2) Faculty of Agriculture, Ain Shams University, Cairo, Egypt.

\begin{abstract}
Aphids are considered serious sap-sucking pests of several plants all over the world. Aphids on medicinal and aromatic plants in Egypt were surveyed throughout the period between 2013 and 2015. Nine aphid species belonging to six genera all represented sub-family Aphidinae were recorded on 26 medicinal and aromatic host plants from different localities in Egypt. Identification taxonomic key for the nine species was designed. Synonyms, historical review, host plants and distribution in Egypt for each aphid species were provided.

Keywords: Survey, Identification, Taxonomic key, Host plants, Medicinal plants, Aromatic plants, Synonyms, Distribution, Egypt.
\end{abstract}

\section{INTRODUCTION}

Over the centuries, the use of medicinal and aromatic plants has become an important part of daily life despite the progress in modern medical and pharmaceutical industry. They are now being progressively cosmetics, foods and teas, as well as alternative medicines. The growing interest in herbs and their ability to offer economical uses is a part of the movement towards greener economics and life styles (Ghorbanpour et al., 2017).

Medicinal and aromatic plants, like crop plants, are also afflicted by arthropod pests including aphids (Gupta, 1991; Abdel-Moniem and Abdel- 
Wahab, 2006; Pal and Sarkar, 2009; Salem, 2009; Bhagat, 2012; Amin et al., 2017). Aphids cause direct damage by sucking plant sap as well as cause indirect damage by secreting honeydew that attract many insects such as flies, ants and wasps, moreover sooty mold will start to grow and finally photosynthesis and yield will be reduced. Furthermore, aphids are responsible for transferring viral diseases from infested plants to healthy plants. (Chan et al., 1991 and Blackman \& Eastop 2000). Surveying aphids on medicinal and aromatic plants attracted many authors all over the world who recorded many aphid species on these plants (Dawood, 1971; Blackman \& Eastop 1984; ElKordy et al., 1999; Karkanis et al., 2011 and Bhagat, 2012; Bayhan et al., 2014). The present work aims at surveying aphid species infest certain medicinal and aromatic plants in Egypt.

\section{MATERIAL AND METHODS}

Collecting and preservation: Aphids were collected from plant vegetation using a camel hair brush, jarring the foliage on a white paper sheet and specimens were transferred into vials containing $70 \%$ alcohol, with few drops of glycerin to the laboratory for the proper identification.

Specimens mounting: Collected aphid species alate forms were previously killed in $70 \%$ ethyl alcohol. After being killed and preserved, they were cleaned with distillated water and macerated in a $10 \%$ sodium hydroxide solution for several times, then washed in 5\% glacial acetic acid. Afterwards samples were dehydrated by series of ethyl alcohol concentration of 50,70 , 80, 90, 95 and $100 \%$, respectively. To have clear specimens, samples were cleared by socking fresh chloral-phenol solution (1 vol. chloral hydrate: 1 vol. 
phenol). Cleared specimens were transferred to clean glass slide with drops of Swan's gum chloral medium (El-Kady, 1959), covered with clean slide cover and kept on a hot plate at $40^{\circ} \mathrm{C}$ for 3 days to dry.

Species identification: Different aphid species were identified using available taxonomic keys developed by Habib and El-Kady, 1961; Martin, 1983; Blackman \& Eastop, 1994 and 2008.

\section{RESULTS AND DISCUSSIONS}

Nine aphid species belonging to six genera all of them represented SubFamily: Aphidinae and classified into two tribes Aphidini and macrosiphini were found infesting 26 medicinal and aromatic plant species belonging to 12 plant families (Table, 1). Tribe Aphidini is represented in this study by four aphid species all of them belonging to genus Aphis; A. fabae (Scopoli), A. gosspyii (Glover), A. nasturtii Kaltenbach and A. nerii Boyer de Fonscolombe, while five aphid species belonging to five genera were belonging to tribe Macrosiphini; Acyrthosiphonpisum pisum (Harris), Brevicoryne brassicae Van Der Goot, Hyadophis coriandri (Das), Macrosiphum rosae (Linnaeus) and Myzus persicae (Sülzer). 


\section{Key to the surveyed aphid genera and species on medicinal and aromatic plants in Egypt}

1. Lateral abdominal tubercles present on segments 1 and $7 \ldots \ldots$ Aphis

This genus is represented here by four species named; fabae, gossypii, nastrutii and nerii.

- $\quad$ Lateral abdominal tubercles absent on segments 1 and $7 \ldots \ldots \ldots \ldots . . .2$

2(1). Frontal tubercles well developed. Siphunculi elongate.............. 3

- Frontal tubercles not or not well developed. Siphunculi short....... 5

3(2). Frontal tubercles converging. Rhinaria on $4^{\text {th }}$ antennal segment only. Dorsum with black patch Myzus

This genus is represented here by one species only named persicae

- Frontal tubercles diverging. Rhinaria on $3^{\text {rd }}$ antennal segment only. Dorsum without black patch

4(3). Post-siphuncular sclerites present. Siphunculi with polygonal reticulated apex Macrosiphum

This genus is represented here by one species only named rosae

- Post-siphuncular sclerites absent. Siphunculi without polygonal reticulated apex Acyrhosiphon

This genus is represented here by one species only named pisum

5(1). Rhinaria on $3^{\text {rd }}$ and $4^{\text {th }}$ antennal segments. Frontal tubercles not well developed. Cauda elongate...... Hyadaphis

This genus is represented here by one species only named corandri

- Rhinaria on $3^{\text {rd }}, 4^{\text {th }}$ and $5^{\text {th }}$ antennal segments. Frontal tubercles not developed. Cauda triangular Brevicoryne This genus is represented here by one species only named brassicae

Genus Aphis This genus is represented on medicinal and aromatic plants in Egypt by four species. 


\section{Key to species}

1. Abdominal tergites 7 and 8 with black markings............... fabae

Abdominal tergites without markings.............................. 2

-- Post-siphuncular sclerites present and large. Unguis about 3 times as long as the basal part..........................................nerii

2(1). Post-siphuncular sclerites absent or small when present. Unguis variable.

-- $\quad$ Secondary rhinaria confined to the $3^{\text {rd }}$ antennal segment only. Siphunculi

3(2). dark. Femural hair short gossypii

-- Secondary rhinaria present on $3^{\text {rd }}, 4^{\text {th }}$ and $5^{\text {th }}$ antennal segments. Sipunculi pale. Femural hairs long. nastrutii

\section{Tribe: Aphidini}

\section{Aphis fabae (Scopoli.)}

Broad bean aphid

\section{Synonyms:}

Aphis aparines Fabricius, 1775

Aphis atriplicis Fabricius, 1775 nec Linnaeus, 1758

Aphis hortensis Fabricius, 1781

Aphis acanthi Schrank, 1801

Aphis fabae Blanchard, 1840

This species was recorded for the first time in Egypt by Hall, 1926 under the name Aphis compositae and compared it with Aphis solanella.

Host plants and geographical distribution in Egypt: During the present work, this species was collected from different localities in Egypt from six ornamental plant species; Celery, Pot marigold, Chamomile, Sunflower, 
African marigold, Sweet basil from four different governorates; Fayoum, Qalyubiya, Giza and Sharqyia

Abul-Nasr et al. (1975) recorded this species infesting many cutflowering plants in certain regions of Egypt. Semeda et al. (2004) recorded Aphis fabae on different host plants such as hibiscus (Hibiscus rosae) and fennel (Foeinculum vugare) in North Sinai, Egypt. Zümreoğlu and Akbulut (1992) in Turkey determined the effects of A. fabae infestation on the oil and morphine contents and seed weight of poppy (papaver somniferum).

\section{Aphis gosspyii (Glover, 1877)}

Cotton aphid

\section{Synonyms:}

Aphis gosspyii (Glover.) 1877

Aphis ligustrella (Theobold.) 1913

Aphis hederella (Theobold.) 1915

Aphis bauhiniae (Theobald.) 1918

Aphis ficus (Theobold.) 1918

This species was first recorded in Egypt by Theobald (1918) under the name Aphis bauhinia on Bauhinia sp., Willcocks (1922) surveyed A. gossypii on violets at Cairo. Eastop (1958) and Hall (1926) recorded specimens of Aphis ficus that was considered as synonym of A. gosspyii.

Host plants and geographical distribution in Egypt: During the present work, this species was collected from 18 aromatic and medicinal plant species from different localities in Egypt. Willcocks (1922) recorded this species on citrus trees in Egypt. Abul-Nasr et al. (1975) detected this species infesting many cut-flowering plants in certain regions of Egypt. Elnagar et al. (1979) 
J. Environ. Sci.

Institute of Environmental Studies and Research - Ain Shams University

recorded this species on three wild plant species in Giza Governorate. Attia (1983) found this species infesting citrus and apple trees in Egypt. Also Attia and El Hamaky (1992) recorded this species on many vegetable plants in Sinai Governorate.

\section{Aphis nasturtii Kaltenbach, 1843}

Buckthorn-potato aphid

\section{Synonyms:}

Aphis abbreviata Patch, 1912

Aphis acetosella Theobald, 1918

Aphis bulleri Robinson \& Rojanavongse, 1976

Aphis cathartica

Aphis crispi

Aphis githaginella

Aphis insons Hottes, 1930

Aphis linguae

Aphis mathiolae Theobald, 1917

Aphis neopolygoni

Aphis pedicularis Buckton, 1879

Aphis plantaginifolii Nevsky, 1929

Aphis rhamni

Aphis transiens Walker, 1849

Aphis zizyphi Theobald, 1917

This species was recorded for the first time in Egypt as A. acetosella by Theobald, 1918 from Rumex dentatus and Papaver sp. 
Host plants and geographical distribution in Egypt: During the period of this work, this species was collected from five aromatic and medicinal plant species; Calendula officinalis, Tagets erects Salanum laciniatum, Mentha peperita and Chrysanthemum sp., from three governorates; Qalyobiya, Giza and Sharqiya. Abul-Nasr et al. (1975) recorded this species infesting many cut-flowering plants in certain regions of Egypt.

\section{Aphis nerii Boyer de Fonscolombe, 1841}

Oleander aphid, Milkweed aphid

\section{Synonyms:}

Aphis asclepiadis (Passerini, 1863).

Aphis calotropidis Del Guercio, 1916.

Aphis foveolata Del Guercio, 1916

Aphis gomphoricarpi Eastop \& Hille Ris Lambers, 1976

Aphis leptadeniae (Vuillet \& Vuillet, 1914).

Aphis lutescens Monell, 1879

Aphis neriastri Boisduval 1867.

Aphis nerii Boyer de Fonscolombe, 1841

Aphis nigripes Theobald, 1914

Aphis paolii Del Guercio, 1916

This species was recorded for the first time in Egypt by Theobald, 1915 on six host plants.

Host plants and geographical distribution in Egypt: During the present work, this species was collected from three ornamental plant species; Jasmine, Spearmint and Bunch flower from five different governorates; 
J. Environ. Sci.

Institute of Environmental Studies and Research - Ain Shams University

Sharqyia, Qalyubiya, Fayoum, Beni-suef and Giza. Attia and El Hamaky (1992) recorded this species on two vegetable plants in Sinai Governorate.

\section{Tribe: Macrosiphini}

\section{Acyrthosiphon pisum (Harris, 1776)}

Pea aphid

\section{Synonyms:}

Aphis pisum by Harris (1776)

Aphis onobrychis B.d.f., Annsa (184)

Aphis lathuychis mosley (1841)

Aphis pisi kaitenbach mono.

Siphonophore spartii Koch.(1955)

Siphonophore ononis Koch.(1955)

Siphonophore pist Koch (1955)

Nectarophora pist sanderson. Delware (1900)

Macrosiphum pisi (Kait.) (1901)

Macrosiphum trifoih pergand.(1904)

Macrosiphum ononts schoutedenn, us (1906)

Acyrthosiphon pist mordwilko, faune(1914)

Acyrthosiphon pisum Hille (1947)

This species was recorded for the first time in Egypt by Theobald (1915) under the name of Macrosiphum pisi (Kait.) on broad beans and sweet beans, then Willcooks, 1922 and Hall, 1926 added nine new host plants

Host plants and geographical distribution in Egypt: During the present work, this species was collected on Sonchus maritima at Qalubiya 
Governorate only. Abul-Nasr et al. (1975) recorded this species infesting many cut-flowering plants in certain regions of Egypt.

\section{Brevicoryne brassicae Van Der Goot, 1915.}

Cabbage aphid

\section{Synonyms:}

Aphis brassicae L., system nature (Editio decime) 1758.

Siphocoryne brassicae Davis, canad. Ent., XLIV (1914)

Brevicoryne brassicae vandergoot. Beitragez. Kennt. Holl. Blattiause. (1915).

The first record of this species in Egypt was by Willcocks (1922) on cabbage and by Hall (1926) on turnip, cauliflower, radish and ornamental stocks. Habib and El-Kady (1961) described this species in Egypt.

Host plants and geographical distribution in Egypt: Collection of this species from different localities in Egypt occurred during 2013 to 2015 seasons from foeniculum, cauliflower, cabbage radish and turnip, at Fayoum, Beni suef, Qalybyia and Sharqyia Governorates.

Azab et al. (1965) recorded this species on Brussels. Amin and ElDafrawy (1981) recorded this species on cabbage. Attia and El Hamaky (1992) recorded this species on two vegetable plants in Sinai Governorate. 
J. Environ. Sci.

Institute of Environmental Studies and Research - Ain Shams University

\section{Hyadaphis coriandri (Das, 1918).}

Coriander aphid

\section{Synonyms:}

Hydaphis corindri (Das). After EC stop (1958).

Hyaloterus obscurus Theobald (1922).

Hyalopteus carii.theobald, after Eastop (1985)

Hyalopteus peucedani Hall, after Eastop (1985)

Hyalopteus conica Borner.after Eastop (1985)

This species was recorded for the first time in Egypt by Theobald (1918) on fennel under the name of Hyalopterus obscurus n. sp. (Willcocks collection).

Host plants and geographical distribution in Egypt: During the present work, this species was collected from three medicinal and aromatic plants from different localities of Egypt. Hall (1926) collected it from Anethum sp., Daucus carota, Coriandrum sativum, Andropogon sp., and Pithyranthus tortuosus. Habib and El-Kady (1961) recorded it on fennel under the name Hyalopterus obscurus. Attia and El Hamaky (1992) recorded this species on two vegetable plants in Sinai Governorate.

Macrosiphum rosae (Linnaeus, 1758).

Rose aphid

\section{Synonyms:}

Aphis dipsaci Schrank

Aphis rosae Linnaeus

Aphis scabiosae Scopoli

Macrosiphon rosae (L.) 
Macrosiphum rosae subsp. fragaricola Hille Ris Lambers

Macrosiphum rosae subsp. orientale Mordvilko

Macrosiphum rosae subsp. vasiljevi Mordvilko

Macrosiphum rosae var. azerbaidshanica Rusanova

Macrosiphum rosae var. scabiosae Rusanova

Nectarophora rosae Oestlund

Passerinia rosae Macchiati

Siphonophora fragariae Koch

Siphonophora rosae Buckton

Siphonophora rosae var. glauca Buckton

Siphonophora rosaecola Passerini

This species was recorded for the first time in Egypt by Willcocks, 1922 and Hall, 1926

Host plants and geographical distribution in Egypt: During the present work, this species was collected from four medicinal and aromatic plants belonging to three families from different localities of Egypt. Abul-Nasr et al. (1975) recorded this species infesting many cut-flowering plants in certain regions of Egypt.

\section{Myzus persicae (Sülzer, 1776).}

Green peach aphid

\section{Synonyms:}

Aphis persicae sulzer.

Rhopalosiphum lactucellum Theobald (1915)

Myzus persicae Sülzer after Hall (1926). 
This species was recorded in Egypt for the first time by Hall (1926). Theobald (1915) described this species in Egypt under the name of Rhopulosiphum lactcellum, which was considered later by Hall (1926) as a synonym to Myzus persicae.

Host plants and geographical distribution in Egypt: During the present work, this species was collected from 10 medicinal and aromatic plant species from different localities in Egypt. Hall (1926) recorded M. persicae on certain host plants; Eruca sativa (Cruciferae). Ammi majus (unbelliferae); Carduus dipsacus (composite); Petunia hybridea (Salanaceae); Lantana camara (Verbenacea); Malva rolundifolia (maluaceae), Dolichos lablab (Leguminosae) Moricandia sp. (Cruciferae). Azab et al. (1965) recorded this species on Brussels sprouts. Dawood (1971) recorded this species on different ornamental plants. Mazen, Ateyyat et al. (2015) studied the activity of M. persicae on rosemary, Menthe rulegium and lavender.

\section{REFERNCES}

Abdel-Moniem, A. S. H. and Abdel-Wahab, T. E. (2006). Insect pests and predators inhabiting roselle plants, Hibiscus sabdariffa L., a medicinal plant in Egypt. Arch. Phytopathol. Plant Protec., 39 (1): 25-32.

Abul-Nasr; S., Swailem, S. and Dawood, M. Z. (1975). Survey of aphids and mealy-bugs infesting some cut flowering plants in certain regions of Egypt. Bull. Ent. Soc. Egypt.; 59: 281-288.

Amin, A. H. and El-Dafrawy, G. M. (1981). Seasonal fluctuations of populations of different aphid species infesting cabbage plants in Egypt. Bull. Soc. Ent. Egypt., 63: 103-109. 
Amin, M.; Mahmood, K. and Bodlah, I. (2017). Aphid species (Hemiptera:Aphididae) infesting medicinal and aromatic plants in the Poonch division of Azad Jammu and Kashmir, Pakistan. The J. of Animal \& Plant Sci., 27 (4): 1377-1385.

Attia, A. A. (1983). Studies on the aphid fauna of fruit trees in Egypt. Ph. D. Thesis, Fac. Agric., Cairo Univ.

Attia, A. A. and El-Hamaky, M. A. (1992). Aphid species in Sinai governorate, Egypt. Bull. Ent. Soc. Egypt, 70: 195-199.

Azab, A. K.; Tawfik, M. F. S. and Ismail, I. I. (1965). Seasonal changes in the in the abundance of certain aphids and their predators in Giza. Bull. Soc. Ent., Egypt., 49:11-24.

Bayhan, E.; Bayhan, S. Ö. and Özdemir, I. (2014). Aphid species (Hemiptera: Aphididae) of South Eastern Anatolia region (Turkey) and their host plants. 5th International Sci. Afric. Sym., 551-555.

Ben Halima, Monia K. (2012). Aphid fauna (Hemiptera: Aphididae) and their host association of Chott Mariem, coastal area of Tunisia. Annals of Biol. Res. 3 (1):1-11.

Bhagat, R. C. (2012). Aphids (Insecta) damaging medicinal and aromatic plants of Jammu and Kashmir State (India): an updated checklist and biodiversity. Indian J. Appl. and Pure Biol.27(1): 1-10.

Blackman, R. L. and Eastop, V. F. (1984). Aphids on the World's Crops: An identification and information guide. Eds., John Wiley and Sons, UK, $476 \mathrm{p}$.

Blackman, R. L. and Eastop, V. F. (1994). Aphids on the World's Trees: An identification and information guide. $\mathrm{CAB}$ International Wallingford, UK, $986 \mathrm{p}$.

Blackman, R. L. and Eastop, V. F. (2000). Aphids on the World's Crops: An identification and information guide. 2nd ed., John Wiley and Sons, Chichester, UK, 414 pp.

Blackman R. L. and Eastop, V. F. (2008). Aphids on the World's herbaceous plants and shrubs. Eur. J. Entomol., 105 (1): 164 - 164.

Chan, C. K.; Forbes, A. R. and Raworth, D. A. (1991). Aphid-transmitted viruses and their vectors of the world. Agric. Canada Res. Branch Tech. Bull. 19913E, 216 pp.

Dawood, M. Z. (1971). Survey of aphids and mealybugs infestation ornamental plants. M. Sc. Thesis, Fac. Agric., Cairo Univ. 
Eastop, V. F. (1958). A study of the Aphididae of East Africa. HMSO, London, $126 \mathrm{pp}$.

El-Kady, E. A. (1959). Taxonomical, ecological and biological studies on Aphidiae (Homoptera) in Egypt. Ph. D. Thesis, Fac. Agric., Ain Shams Univ., $253 \mathrm{pp}$.

El-Kordy, M. W.; Mohamed, A. A.; Marzouk, I. A. and Mohamed, H. A. (1999). The changes in population density of aphids attacking some medicinal and aromatic plants in Egypt. Egypt. J. Agric. Res., 77 (1): 195-204.

Elnagar, S.; Megahed, M. M. and Amin, A. H. (1979). The aphid fauna of wild plants in Egypt. Bull. Soc. Ent. Egypte, 62: 219 - 226.

Ghorbanpour, M.; Hadian, J.; Nikabadi, S. and Varma, A. (2017). Importance of medicinal and aromatic plants in human life. In Medicinal Plants and Environmental Challenges. Springer, Cham. 1 - 23.

Gupta, R. (1991). Agrotechnology of medicinal plants. Wijesekera ROB (ed.). The medicinal plant industry. CRC Press, Boca Raton, pp. 43-57.

Habib, A. and El-Kady, E. A. (1961). The Aphididae of Egypt. Bull. Soc. Entomol. Egypt., 45: 1-137.

Hall, W. Y. (1926). Notes on the Aphididae of Egypt. Tech. Serv. Bull., 68: 30-41.

Karkanis, A.; Bilalis D. and Efthimiadou, A. (2011). Cultivation of milk thistle (Silybum marianum L. Gaertn.), a medicinal weed. Ind. Crops and Products, 34(1): 825-830.

Kaygin A. T.; Gorur, G. and Sade, F. C. (2009). Aphid (Hemiptera: Aphididae) species determined on herbaceous and shrub plants in Bartin Province in Western Blacksea Region of Turkey. Afr. J. Biotechnol.; 8 (12): 2893-2897.

Martin, J. H. (1983). The Identification of common aphid pests of tropical agriculture. Int. J. Pest Manage., 29 (4): 395-411.

Mazen Ateyyat; Hakimi, Sakina and Mustapha, B. (2015). Insecticidal activity of five essential oils of Algerian medicinal plants on peach potato aphid, Myzus persicae (Homoptera:Aphididae). Advances in Environmental Biology, 9 (2): 89-94.

Pal, S. and Sarkar, I. (2009). Pests infesting ornamental plants in hilly region of West Bengal. The J. Plant Protec. Sci., 1 (1): 98-101. 
Salem, M. A. (2009). Ecological studies on aphids infesting some ornamental plants. M. Sc. Thesis, Fac. Agric., Ain Shams Univ., 177 pp.

Semeda, A. M.; Ismail, I. I. and Abdel-Salam, A. A. (2004). Host range and population density of Aphis fabae Scop. in Sinai Governorates, Egypt. Proc. 6th Internat. Sym. on aphids, 171-175.

Theobald, F. V. (1915). African Aphididae. Ibid, 6: 103.

Theobald, F. V. (1918). African Aphididae. Ibid, 6: 273.

Willcocks, F. C. (1922). A survey of the most important economic insects and mites of Egypt. Sult. Agric. Soc. Bull. 1. 482 pp.

Zümreoğlu, S. and Akbulut, N. (1992). Investigations on the effects of different population densities (Aphis fabae Scop. and Acyrthosiphon ilka Mord.) (Homoptera:Aphidiae) on oil and morphine and seed weight in poppy heads. Proc. 2nd Turkish Nat. Cong. of Entomol., 559-569.

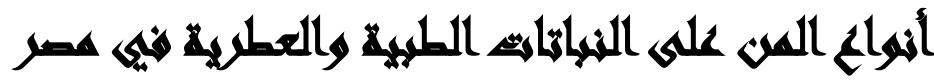

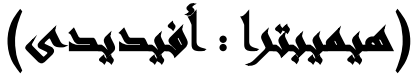

$[r]$

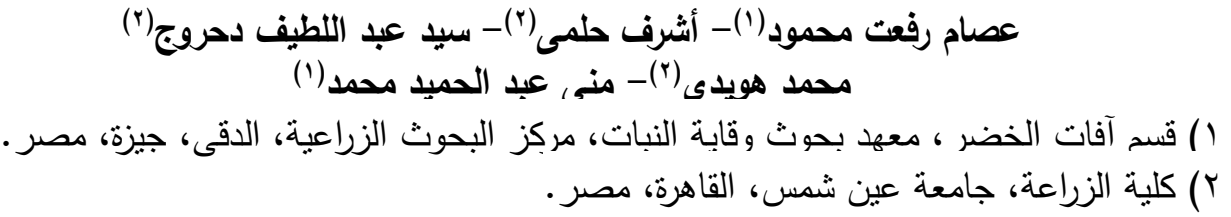

\section{المستحلص}

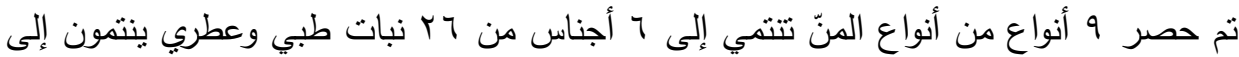

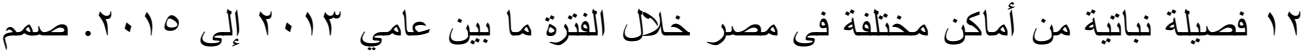

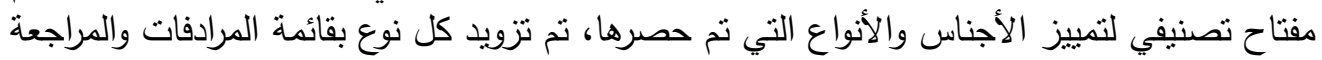
التاريخية والعوائل النباتية والتوزيع الجغرافي في مصر الأناع 